\title{
SKEMA PENTASYARUFAN ZAKAT UNTUK PENANGGULANGAN COVID 19
}

(Study Analisi Kritis Fatwa MUI No 23 Tahun 2020 Tentang Pemanfatan Harta Zakat, Infak, Dan Shadaqah Untuk Penanggulangan

Wabah Covid-19 Dan Dampaknya)

\author{
Agus Salim \\ Universitas Nadlatul Ulama Purwokerto \\ agussalimsiogut@gmail.com
}

\begin{abstract}
Zakat is one of the obligatory worship with detailed explanation in the Qur'an and Hadits, both about the subject, object, degree of obligation and to whom is given. A few months ago, a Fatwa from the Indonesian Ulema Council (MUI) appeared on the introduction of zakat for the handling of covid-19 victims and their handlers. From this fatwa then negative assumptions are formed, as if the zakat property is not assigned to the existing zakat according to the guidance of the Qur'an and the Hadits. In this paper the author tries to scheming the contents of the fatwa using the methodology of liberry risert, it is hoped that what is stated in the fatwa of the preaching of zakat and shadaqah can be understood by the public well.
\end{abstract}

Keywords: Zakat, Fatwa of MUI, Distribution of Zakat, Handling the Covid-19 Outbreak.

\section{Pendahuluan}

Pandemi Covid 19 bukan hanya membuat masyarakat takut terhadap penularan dan penyebaranya, tapi masyarakat juga takut 
terhadap kebijakan pemerintah perihal akibat dari Pembatasan Sosial Berskala besar (PSBB) akan melumpuhkan perekonomian mereka. IMF sebagaimana dikutip oleh BBC memprediksi output ekonomi dunia tahun ini akan menyusut hampir 5\%, atau hampir 2\% lebih buruk dari perkiraan yang dirilis pada bulan April 2020. ${ }^{1}$ Ketakutan Pembatasan Sosial Berskala Besar bukan ispan jempol semata. Rilisan terbaru sebagiamana dikutip Kompas pada 15 Juni 2020 menyebutkan adanya peningaktan jumlah penduduk miskin sebanyak 1,63 juta orang dibandingkan periode September 2019. ${ }^{2}$

Di Indonesia sendiri riwayat masuknya covid tercatat dimulai pada 02 Maret 2020. ${ }^{3}$ Hingga saat penulis menulis artikel ini yakni pada tanggal 04 September 2020 jumlah pasien covid telah mencapai 187.537 orang, dengan penambahan pasien 3.269 orang setiap harinya. ${ }^{4}$ Artinya pandemi covid 19 tidak kunjung usai meski segala upaya pencegahannya telah dilakukan.

Kebijakan ekonomi sebenarnya telah diupayakan oleh pemerintah untuk mengantipasi ancaman Covid 19. Setidaknya ada Sembilan kebijakan yang pemerintah keluarkan untuk mengantipasi acaman Covid 19 pada sektor ekonomi, Pertama, gubernur dan wali kota memangkas rencana belanja yang bukan belanja prioritas dalam Anggaran Pendapatan dan Belanja Negara (APBN) dan Anggaran Pendapatan dan Belanja Daerah (APBD). Kedua. pemerintah pusat dan pemerintah daerah mengalokasikan ulang anggarannya untuk mempercepat pengentasan dampak Covid 19, baik dari sisi kesehatan dan ekonomi. Ketiga, pemerintah pusat serta pemerintah daerah menjamin ketersediaan bahan pokok, diikuti dengan memastikan terjaganya daya beli masyarakat, terutama masyarakat lapisan bawah. Keempat, program Padat Karya Tunai diperbanyak dan dilipat gandakan, dengan catatan harus diikuti dengan kepatuhan terhadap protokol pencegahan virus Covid 19. Kelima. pemerintah memberikan tambahan sebesar Rp 50.000 pada pemegang kartu sembako murah selama enam bulan. Keenam, Presiden mempercepat impelemntasi kartu pra-kerja guna mengantisipasi pekerja yang terkena PHK pekerja, kehilangan penghasilan, dan

\footnotetext{
${ }^{1}$ https://www.bbc.com/indonesia/dunia-53168814

2 https://money.kompas.com/read/2020/07/15/150436926/bps-dampak-covid-19penduduk-miskin-naik-jadi-2642-juta-orang?page $=$ all.

3 https://www.kompas.com/sains/read/2020/05/11/130600623/diumumkan-awalmaret-ahli--virus-corona-masuk-indonesia-dari-

januari\#: :text=KOMPAS.com $\% 20 \% 2 \mathrm{D} \% 20$ Pada $\% 202 \% 20$ Maret,ke $\% 20$ Indonesia $\%$ 20sejak\%20awal\%20Januari.

4 https://www.cnnindonesia.com/nasional/20200904151608-20-542861/updatecorona-4-september-187537-positif-134181-sembuh
} 
penugusaha mikro yang kehilagan pasar dan omzetnya. Ketujuh, pemerintah juga membayarkan pajak penghasilan (PPh) Pasal 21 yang selama ini dibayar oleh wajib pajak (WP) karyawan di industri pengolahan. Alokasi anggaran yang disediakan mencapai Rp 8,6 triliun. Kedelapan, Otoritas Jasa Keuangan (OJK) memberikan relaksasi kredit di bawah Rp 10 miliar untuk Usaha Mikro Kecil dan Menengah (UMKM). Kesembilan, masyarakat berpenghasilan rendah yang melakukan kredit kepemilikan rumah (KPR) bersubsidi, akan diberikan stimulus. ${ }^{5}$

Dampak covid 19 tidak hanya pada sektor ekonomi masyarakat saja, namun covid 19 juga memberi dampak serius terhadap pendidikan di Indonesia. Dampak covid 19 pada pendidikan di Indonesia yang dimaksud adalah terhalangnya pelajar tingkat dasar hingga perguruan tinggi untuk belajar secara tatap muka, alhasil belajar mengajar dilakukan dengan cara during. Kebijakan belajar during memunculkan masalah ekonomi baru, di mana para pelajar membutuhkan dana untuk membeli pulsa kuota setiap kali belajar during, sementara itu pekerjaan orang tua yang menjadi sumber dana belajar mereka saat pandemi tidak seoptimal masa normal. Masalah ini mendapat respon dari pemerinta setelah tiga bulan lebih pelajar belajar during. Pemerintah melalui mentri perekonomian dan mentri Pendidikan telah mengeluarkan kebijakan subsidi pulsa kuota.

Perkembangan terakhir pengaruh pandemi covid 19, negaranegara di ambang resesi tidak terkecuali Indonesia. Beberapa kebijakan perekonomian diharapkan dapat menghindarkan atau meminimalisasi resesi. Salah satu kebijakan dalam upaya menangani masalah ekonomi adalah upaya pengoptimalkan penglolahan zakat untuk penangulngan covid 19. Majelis Ulama Indonesia (MUI) dalam hal ini telah mengeluarkan fatwa tentang pemanfaatan zakat untuk penanggulangan covid 19.

\section{Zakat Menurut Hukum Islam Klasik}

Sejarah pensyari'atan zakat telah banyak di bahas di beberapa literatur figh, tercatat zakat disyari'atkan pada bulan syawal tahun ke 2 hijrah setelah diwajibkannya puasa bulan Ramadhan pada tahun itu pula. ${ }^{6}$ Pendapat ini menurut banyak ulama adalah pensyari'atan zakat fitrah. Sedang ada pula ulama yang mengatakan bahwa zakat disyari'atkan sebelum Rasul dan sahabat hijrah ke Makkah. Hal ini mengarah pada

5 https://nasional.kompas.com/read/2020/03/26/07412441/9-kebijakan-ekonomijokowi-di-tengah-pandemi-covid-19-penangguhan-cicilan?page $=$ all

${ }^{6}$ Wahbah Zuhaili, al Fiqh al Islami wa Adilatubu, (Beirut, Dar al Fikr, 2014). Juz. II. Hlm. 645 
lafat shadaqah dalam qur'an, di mana para kaum muslim saat di Makah dianjurkan oleh syari'at untuk saling membantu satu sama lainya. Pada saat di Makkah zakat tidak dibatasi komoditasnya dan kadarnya, namun setelah tahun ke 2 Hijrah, zakat mulai ditentukan komoditas dan kadarnya oleh nabi dalam beberapa kesempatan.

Para ulama mengklasifikasi istilah zakat menjadi dua bagian yakni istilah umum dan khusus. Lafath Zakat yang sering muncul dalam kitabkitab kuning sebagai istilah khusus, sedangkan beberapa kitab dan ayat qur'an menyebut shadaqah sebagai istilah zakat secara umum. Dengan keumumannya, istilah shadaqah oleh fuqaha' kemudian diklasifikasi dengan menyebut shadaqah al wajib dan shadaqah at tatawu'. Shadaqah al wajib yang dimaksud adalah zakat, sedangkan shadaqah at tatawn' adalah shadaqah sunnah atau suatu pemberian kebajikan yang diberikan pada orang lain tanpa pamrih.

Zakat menurut bahasa an Nama', ${ }^{8}$ htat Taìr dan at Taksìr ${ }^{9}$ yakni bertambah, mensucikan, dan memperbanyak, sedangkan menurut syara' zakat adalah suatu ungkapan untuk harta tertentu yang diambil dari seorang tertentu, dengan cara tertentu, dan ditasyarufkan kepada kelompok tertentu. ${ }^{10}$ Syamsudin dalam kitabnya melengkapi, menurutnya zakat adalah ungkapan bagi sesuatu yang dikeluarkan dari harta atau badan seseorang dengan cara tertentu. ${ }^{11}$ Jika kita cermati, definisi ini membingkai istilah zakat kepada orientasi zakat, bahwa zakat dikelurakan untuk membersikan harta benda dan jiwa seorang yang menunaikannya. Pasal 1 Undang-undang No 23 Tahun 2011 tentang Penglolaan Zakat mendefinisikan zakat sebagai harta yang wajib dikeluarkan oleh seorang muslim atau badan usaha untuk diberikan kepada yang berhak menerimanya sesuai dengan syariat Islam. ${ }^{12}$

Zakat disebut zakat karena ia dapat membersihkan jiwa dan harta seorang yang menuaikannya dari hak-hak penerima zakat. Zakat juga dapat membersikan diri seseorang yang menunaikannya dari dosa, zakat dapat memperbaiki harta dan meperbaiki sikap seorang yang menunaikannya dari sifat tercela, dan juga mencegah orang yang

\footnotetext{
${ }^{7}$ Muhammad bi Idris as Syafii, al 'Umm, (Beirut, Dar al Kotob al Ilmiyah, 2014), Juz II. Hlm. 4

${ }^{8}$ Ibrahim bin Ali al-Fayruz Abadi, Al Muhaddab fi Fiqh al-Imam Syafii, (Beirut, Dar al Kotob al Ilmiyah, 2011). Juz.I hlm. 260

9 Syamsu al Din Muhammad. Nihayatu al Mubtaj ila Syahri al Mubadzab, (Mesir, al Maktabah al Taufikiya, 2012). Juz III. Hlm.65

${ }^{10}$ Ibrahim al Bayjori, Hasyiah as Syaikh Ibrahim al Bayjori ala Syarah Ibnu Qasim al Ghazzi ala Matn Abi Suja’. (Beirut, Dar al Kotob Al -Ilmiyah, 2015). Juz.I, Hlm. 499

${ }^{11}$ Syamsu al Din Muhammad. Nihayatu al Mubtaj..65

${ }^{12}$ Lihat Undang-undang No 23 Tahun 2011 tentang Penglolaan
} 
menunaikannya dari segala bahaya. ${ }^{13}$ Hal ini selaras dengan al Qur'an Surat at Taubah Ayat 103.

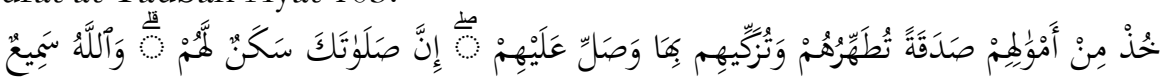

Ambillah zakat dari sebagian harta mereka, dengan zakat itu kamu membersihkan dan mensucikan mereka dan berdoalah untuk mereka. Sesungguhnya doa kamu itu (menjadi) ketenteraman jiwa bagi mereka. Dan Allah Maha Mendengar lagi Maha Mengetahui.

Lebih lanjut Sayid Sabiq menjelaskan apa yang dimaksud zakat dapat mensucikan dan membersikan. Menurutnya yang dimaksud dengan zakat dapat mensucikan orang yang menunaikannya adalah pemberi zakat akan suci dari sifat pelit dan tama' dalam hatinya, di mana dua sifat ini adalah sifat tercela. Selain itu muzaki akan suci atau terhindar dari sikap atau prasangka buruk kepada orang fakir dan suci dari sifat tercela. Sedang menurut Sabiq yang dimaksud dengan tambahnya harta seseorang setelah menunaikan zakatnya adalah dimudahkannya seseorang mendapatkan harta dengan cara yang halal, dan dimudahkannya menggunakan harta dalam hal kebaikan. Selain itu harta yang telah ditasyarufkan akan menjadi barkah bagi sesame, sehingga pemberi zakat mendapat kebahagian duniah dan akhirat. ${ }^{14}$

Dilihat dari fungsi zakat di atas, zakat adalah ibadah yang tidak kala pentingnya dengan shalat. Selain zakat merupakan ibadah yang memiliki nilai spiritual yang penting. Zakat juga memiliki nilai social yang tidak kalah penting. Begitu pentingnya zakat, wajar lafat zakat dalam qur'an banyak disebut berbarengan dengan lafat shalat. Beberapa peneliti menyebutkan setidaknya ada dua pulu empat ayat yang menyebutkan lafat zakat beriringan dengan lafat shalat. Dua pulu empat ayat tersebut salah

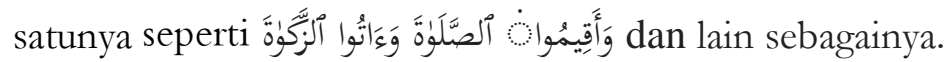

Meski zakat merupakan ibadah yang sama penting dengan shalat, subjek wajib zakat tidak sebagaimana subjek wajib shalat. Jika dalam shalat subjek wajibnya adalah Islam, Baligh, Aqil dan suci dari Hadats, ${ }^{15}$ maka dalam zakat subjek wajibnya adalah Islam, merdeka dan memiliki objek zakat secara sempurna dan bukan kepemilikan dari hasil hutang dan telah mencapai satu nisab. ${ }^{16}$ Secara social, semua muslim baik kaya

\footnotetext{
${ }^{13}$ Syamsu al Din Muhammad. Nihayatu al Mubtaj .65

14 Sayid Sabiq.Fiqhu as Sunnah, (Beirut, Maktabah al Ashriyah 2011). Juz I. Hlm. 247

15 Muhammad az Zuhri. Anwar al Masalik Syarah Umdatu as Salik wa Umdatu an Nasik. (Surabaya, al Hidayah. TT) Hlm. 35

${ }^{16}$ Muhammad az Zuhri. Anwar al Masalik.102
} 
atau miskin wajib shalat, kecuali yang tidak berakal dan masih belia, tapi dalam kewajiban zakat, subjek wajib zakat adalah semua muslim yang mampu menunaikan zakat, meski ia tidak berakal ataupun masih belia. Dalam syariat Islam, seorang muslim yang tidak berakal dan seorang yang masih belia kewajiban zakatnya dibebankan pada walinya. Berbeda dengan pendapat pengikut imam Hanafi, mereka mengatakan tidak ada kewajiban zakat Mäll bagi anak-anak yang belum baligh dan juga orang gila. Menurut mereka anak-anak yang belum baligh dan orang gila bukan termasuk seorang terkena taklif zakat seperti halnya tidak adanya kewajiban shalat pada mereka. ${ }^{17}$ Menurut pendapat pengikut imam Syafi'I, seorang yang tidak wajib zakat adalah hanya seorang budak, sehingga seorang yang memiliki budak tidak wajib baginya mengeluarkan zakat untuk budaknya. ${ }^{18}$

Seseorang yang dipandang wajib zakat, maka wajib baginya mentasyarufkan zakatnya kepada Asnäf zakat. Adapun berkaitan tentang hukum me-nta'khir (mengakhirkan pentsyarufan) zakat atau me-nta'jil (mengeluarkan sebelum waktu wajib) zakat, maka dalam hal ini Fuqha' tidak memperkenankan mengakhirkan zakat tanpa adanya udzur, namun bila ada udzur untuk menunaikan, maka tidak masalah mengakhirkan penunaian zakat. Semisal, harta wajib zakat telah memasuki masa haul dan sudah mencapai satu nisab, namun pemilik sedang sibuk mengurusi urusan perusahaannya, maka dalam keadaan ini seorang boleh mengakhirkan zakat. ${ }^{19}$ Contoh yang lain, Muzaki mengakhirkan zakat karena harta zakatnya tidak berada di sisinya sehingga ia harus mengambilnya di rumah, di mana antara ia dan rumah membutuhkan waktu yang lama hingga berhari-hari, maka boleh bagi Muraki mengakhirkan zakat hingga ia sampai rumah. Hal yang sama, yakni boleh mengakhirkan menunaikan zakat, jika saja di sisinya tidak ada Asnäf (penerima) zakat atau ada Asnäf zakat tapi di wilayah zakat (tempat) lain, maka dalam hal ini juga masih diperbolehkan seorang Muzaki mengakhirkan penunaian zakat.

Bagi orang yang mengakhirkan zakat tanpa udzur, maka ia mendapat dosa, dan apabila harta yang akan dikeluarkan untuk zakat rusak pada saat wajib zakat namun belum dikeluarkan zakatnya, maka wajib baginya mengganti zakatnya. ${ }^{20}$ Jika dalam mengakhirkan zakat kemudian harta wajib zakat hilang atau rusak setelah wajib zakat, namun

\footnotetext{
17 Wahbah Zuhaili, al Figh al Islami.651

18 Zaynudin al Malibari, Fathul Mu’in, (Beirut, Dar al Kotob al Ilmiyah, 2015), Hlm. 77

${ }^{19}$ Wahbah Zuhaili, al Fiqh al Islami.663

${ }^{20}$ Zaynudin al Malibari, Fathul Mu'in. 81
} 
pada saat itu diakhirkan penunaian zakatnya, maka muzaki tetap wajib mengeluarkan zakatnya.

Bagi Muzaki yang enggan menunaikan zakat, maka mereka diancam akan mendapat siksa yang pedih di akhirat kelak. Sedangkan di dunia, orang yang enggan mengeluarkan zakat dapat disanksi, dan boleh bagi penguasa atau pemegang otoritas yang lain untuk mengambil paksa harta zakat yang harus ditunaikan oleh Muzaki. ${ }^{21}$ Semisal, dua orang yang berserikat pada suatu usaha hewan ternak, salah satu dari orang yang berserikat tersebut enggan menunaikan zakat, padahal hewan tersebut sudah mencapai satu nisab dan satu haul, maka dalam masalah ini, penguasa boleh memaksa pemimilik yang enggan menunaikan zakatnya. Selain penguasa menurut al Jurjanī sebagaimana dikutip Zaynudin, sekutu yang lain juga diperkenankan mengambil paksa zakat hewan yang disekutukan dengan orang yang enggan mengeluarkan zakat. Dalam hal salah satu sekutu menunaikan zakat, maka cukup salah satu seorang yang berserikat melakukan niat dalam menunaikan zakat, artinya tidak ada kewajiban kedua sekutu usaha untuk berniat zakat, namun jika keduanya berkenan berniat ketika menunaikan zakat, maka hal tersebut adalah baik. $^{22}$

Fukoha' juga tidak memperbolehkan me-ntajil (mengawalkan) zakat Mäll manakala harta zakat belum mencapai satu nisab. Ketidak bolehan me-nta'ril zakat sebelum haul menurut Fukoha' adalah karena tidak ditemukan sebab wajib zakat pada harta yang belum mencapai satu nisab. Hal ini diqiyaskan pada hukum tidak diperkenankan memberi harga barang kepada penjual sebelum penjual menjual barangnya, atau diqiyaskan pada hukum tidak sah seseorang membayar diat pembunuhan sebelum seorang tersebut membunuh. Namun ulama bersepakat diperkenankan me-nta'jil zakat sebelum haul dengan syarat harta yang dikeluarkan zakatnya telah mencapai satu nisab. ${ }^{23}$

Berbeda dengan pandangan Dahiriyah dan Malikiyah, mereka berpendapat meski harta zakat telah mencapai satu nisab, namun belum satu haul, tidaklah boleh mengeluarkan zakatnya, hal ini karena mereka beralasan bahwa kewajiban zakat itu karena sebab masuknya haul, seperti wajib shalat karena masuknya waktu shalat, sehingga shalat yang dilakukan sebelum masuk waktu shalat tidaklah sah. Syafiiyah berpendapat me-nta'jil zakat sebelum haul tetap sah manakala mengikuti syarat me-nta'jil zakat. Pertama, Mu₹aki adalah orang wajib zakat samapi masuk haul atau masuknya bulan Syawal bagi zakat fitrah, sehingga jika

\footnotetext{
${ }^{21}$ Wahbah Zuhaili, al Figh al Islamī.646-647

22 Zaynudin al Malibari, Fathul Mu'in.82

${ }^{23}$ Wahbah Zuhaili, al Figh al Islami.665
} 
ternyata Muzaki meninggal atau harta yang wajib dikeluarkan kurang satu nisab karena rusak atau hilang sebelum haul, zakatnya tidak dikatakan sah, dalam kondisi harta zakat rusak atau hilang sebelum haul dan Muraki telah menunaikan zakatnya, maka Muzaki dapat menarik kembali harta zakat yang telah ditunaikan. Jika apa yang telah ditunaikan tidak ditarik kembali, maka harta tersebut menjadi shadaqah. Kedua, Asnäf yang diberi zakat sebelum masuk haul adalah orang yang masih bersetatus Asnäf zakat, sehingga andai kata dengan zakat yang ditunaikan oleh Muzaki menyebabkan Asnäf menjadi kaya sebelum haul harta zakat, maka tidak sah zakatnya. ${ }^{24}$ Pendapat Syafi'iyah ini bisa dikata merupakan pendapat yang logis, sebab bagiamanpun juga Muraki dianggap menjadi Muraki manakala harta zakatnya telah mencapai satu nisab dan telah mencapai satu haul, dan dikatakan Asnäf manakala ia beesetatus sebagai salah satu dari delapan Asnäf zakat sampai baul zakat tiba.

Selain menetapkan subjek wajib zakat, syari'at juga menetapkan komoditas apa saja yang merupakan ketegori wajib zakat. Dalam hal in syar'iat Islam klasik mewajibkan beberapa komoditas yang wajib ditunaikan zakat Mäll-nya. Komoditas itu meliputi, emas, perak, tanaman palawija, buah-buahan, harta perdagangan, hewan ternak, hasil tambang, dan benda berharga yang ditemukan dari tanah atau dapat disebut harta karun. ${ }^{25}$ Di antara beberapa komoditas ini, sebagian memiliki masa wajib zakat yang disebut haul dan ada pula yang tidak memiliki masa wajib zakat. Dalam arti lain, komoditas yang memiliki masa wajib zakat, kewajiban zakat pada komoditas ini ditunaikan jika telah samapai satu tahun. Sedangkan komoditas yang tidak memiliki masa wajib zakat, kewajiban zakat pada komoditas ini setela komoditas dipanen atau ditambang. Selain memiliki masa wajib zakat (haul). Kewajiban zakat pada semua komoditas wajib zakat selain dipengaruhi maswa wajib zakat, juga dipengaruhi kadar atau nisab harta zakat. Di mana kadar komoditas zakat menentukan komoditas tersebut wajib dizakati atau tidak wajib dizakati. Di dalam table berikut akan diuraikan awal kadar pada komoditas zakat.

\begin{tabular}{|l|l|l|l|l|}
\hline No & Komoditas & Kadar & Konversi & $\begin{array}{l}\text { Jumlah Wajib } \\
\text { Zakat }\end{array}$ \\
\hline 1 & Emas & 20 Dinar & 85 Gram & $2,5 \%$ \\
\hline 2 & Perak & 200 Dirham & $672 \mathrm{Gram}$ & $2,5 \%$ \\
\hline 3 & Tanaman & 5 wasak & $653 \mathrm{~kg}$ & $\begin{array}{l}10 \% \text { jika tanpa } \\
\text { biaya perairan, } \\
5 \% \text { jika ada }\end{array}$ \\
\hline
\end{tabular}

${ }^{24}$ Wahbah Zuhaili, al Figh al Islami. 666

25 Sayid Sabiq.Fiqhu as Sunnah. 256

148 Agus Salim - Pentasayrufan Zakat Untuk Penanggulangan Covid-19 


\begin{tabular}{|c|c|c|c|c|c|}
\hline & & & & & biaya perairan \\
\hline 4 & $\begin{array}{l}\text { Buah- } \\
\text { buahan }\end{array}$ & \multicolumn{2}{|l|}{5 wasak } & $653 \mathrm{~kg}$ & $\begin{array}{l}10 \% \text { jika tanpa } \\
\text { biaya perairan, } \\
5 \% \text { jika ada } \\
\text { biaya perairan }\end{array}$ \\
\hline 5 & $\begin{array}{l}\text { Barang } \\
\text { Dagangan }\end{array}$ & \multicolumn{2}{|l|}{20 Dinar } & 85 Gram & $2,5 \%$ \\
\hline 6 & $\begin{array}{l}\text { Barang } \\
\text { Tanbang }\end{array}$ & \multicolumn{2}{|l|}{20 Dinar } & 85 Gram & $2,5 \%$ \\
\hline 7 & $\begin{array}{l}\text { Harta } \\
\text { Karun }\end{array}$ & \multicolumn{2}{|l|}{20 Dinar } & 85 Gram & $2,5 \%$ \\
\hline \multirow[t]{3}{*}{8} & \multirow[t]{3}{*}{$\begin{array}{l}\text { Hewan } \\
\text { Ternak }\end{array}$} & Kambing & \begin{tabular}{|l|}
$40-$ \\
120 \\
ekor
\end{tabular} & & 1 Ekor kambing \\
\hline & & Sapi & \begin{tabular}{|l}
$30-$ \\
40 \\
Ekor
\end{tabular} & & 1 Ekor sapi tabi' \\
\hline & & Unta & \begin{tabular}{|l|}
$5-9$ \\
Ekor
\end{tabular} & & 1 Ekor kambing \\
\hline
\end{tabular}

Dalam perkembangan hukum Islam kontrmporer, komoditas wajib zakat tidak hanya pada beberapa hal di atas. Ulama kontemporer telah melakukan suatu terobosan hukum dengan cara mengqiaskan komoditas baru (secara subtansi sama, yakni sama-sama Mäll) dengan komoditas wajib zakat yang telah ditetapkan pada masa Islam klasik, sehingga dalam perkembangannya komoditas wajib zakat masa kontemporer menjadi komlplek dan lebih luas. Sabiq dalam kitabnya menjelaskan adanya kewajiban zakat pada uang kertas yang disimpan di bank dan juga wajib zakat pada kupon obligasi. Selain itu Sabiq juga mewajibkan zakat mahar pernikahan, dan hasil sewa rumah. Beberapa komoditas wajib zakat tersebut ia qiaskan pada zakat Tijarah. ${ }^{26}$ Hal yang sama dikutip oleh Wahbah dalam kitabnya, menurutnya Jumhur ulama berpendapat bahwa tanah yang disewakan atau dipinjamkan wajib ditunaikan zakatnya oleh penyewa atau peminjam sawa yang ditanaminya. ${ }^{27}$

Di Indonesia Badan Amil Zakat Nasioanl (BAZNAS) menetapak zakat profesi atau pendapatan, sehingga bagi mereka yang berpendapatan Rp.5.240.000 perbulanya sudah wajib zakat $2.5 \%$ dari pendapatannaya. ${ }^{28}$

\footnotetext{
${ }^{26}$ Sayid Sabiq.Fiqhu as Sunnah.258

27 Wahbah Zuhaili, al Fiqh al Islami.736

${ }^{28}$ Lihat Keputusan Ketua Badan Amil Zakat Nasioanl No 142 Tahun, 2017 tetang Nilai Nisab Zakat Pendapatan Tahun 2017 di seluruh Wilayah Indonesia
} 
Lebih jelas lagi pada pasal 4 Undang-undang No 23 Tahun 2011 tentang penglolahan zakat menyebutkan, bahwa zakat dapat diklasifikas menjadi dua bagian, yakni zakat fitra dan Zakat Mäll. Zakat Mäll dalam pasal tersebut menyebutkan, bukan hanya pada komodiatas emas dan perak, tapi juga logam mulia, uang dan surat berharga. Bukan hanya pertanian, tapi juga kehutanan, peternakan dan perikanan, dan begitu juga bukan hanya pertambangan melainkan juga perindustrian dan juga pendapatan dan layanan jasa. ${ }^{29}$ Beberpa komoditas tersebut yang harus ditunaikan zakatnya karena jalan qiyas dan atas dasar prinsip adanya tambahan jumlah dan laba.

Berkaitan tentang harta yang wajib dizakati, syari'at mensyaratkan harta yang wajib ditunaikan zakatnya dengan beberapa syarat. Wahbah menjelaskan harta yang wajib ditunaikan zakatnya adalah harta benda yang nilai atau hasilnya tambah atau meningkat setiap tahunya. Harta benda yang wajib ditunaikan zakatnya juga harus mencapai satu nisab. Harta benda yang wajib ditunaikan zakatnya merupakan harta yang dimiliki secar sempurna. Harta yang wajib ditunaikan zakatnya harus ada selama satu tahun (hal ini tidak semua harta zakat harus mengikuti haul atau masa satu tahun), dan yang terakhir adalah harta yang wajib ditunaikan zakatnya tidak merupakan harta hasil hutang untuk mencapai nisabnya. ${ }^{30}$

Dengan adanya syarat harta yang wajib dizakati merupakan barang atau harta benda yang memiliki sifat tambah (meningkat) nila dan jumlah barangnya. Tidak wajib zakat pada sesuatu yang tidak meningkat jumlah barangnya atau nilai jualnya, seperti seperti tidak wajib zakat pada mobil pribadi yang tidak diperdagangkan. Hal ini dikarekan dilihat dari niali jual mobil pribadi relative selalu menurun setiap tahunnya. Begitu juga berkaitan tentang adanya syarat harta yang wajib ditunaikan zakatnya adalah merupakan bukan harta atau barang hutang, maka tidak wajib zakat jika seorang memiliki harta satu nisab dihasilkan dari hutang. Semisal seorang berhutang dari bank Rp.100.000.000 sebagai modal usaha, namun selama setahun dana tersebut tidak digunakan hingga masuk masa haul, maka dana tersebut tidak wajib dizakati. Begitu juga tidak wajib zakat harta dagangan yang merupakan barang titipan dari sales, dimana system pembayaranya adalah dengan cara barang terjual baru bayar.

Hal yang tidak kalah penting, pada saat menunaikan zakat seorang haruslah berniat menunaikan zakat hartanya atau zakat fitrahnya. Sebagaimana dinukil oleh Wahbah, menurutnya Syafi'iyah hokum niat

${ }^{29}$ Lihat Undang-undang No 23 Tahun 2011 tentang Penglolaan Zakat
${ }^{30}$ Wahbah Zuhaili, al Figh al Islami.652-658

150 Agus Salim - Pentasayrufan Zakat Untuk Penanggulangan Covid-19 
pada saat menunaikan zakat adalah wajib. Contoh lafat niat zakat yang sederhana "Hadza Zakatu Mälli (ini adalah zakat hartaku). Pendapat yang hampir sama ditunjukan oleh pendapat Malikiyah yang mensyaratkan adanya niat saat menunaikan zakat. Sedang apakah niat zakat harus berbarengan dengan pemeberian zakat atau tidak, syafi'yah berependapat, penunaian zakat yang menggunakan wakil boleh mendahulukan niat zakat saat Muzaki memberikan harta zakat pada wakilnya. Dan niat zakat Muzaki kepada wakilnya dilakukan saat Muraki dan wakil belum berpisah tempat. $^{31}$

\section{Skema Pentasyarufan Zakat Menurut Hukum Islam Klasik dan Kontemporer}

Pada dasarnya pentasyarufan zakat dapat dilakukan secara langsung oleh Muraki kepada Asnäf zakat secara langsung, namun pentasyarufan zakat juga dapat dilakukan oleh wakil, penguasa atau badan tertentu yang ditunjuk oleh penguasa untuk mengelolah zakat. Adapun siapa saja Asnäf zakat, telah dijelaskan secara tegas pada ayat berikut.

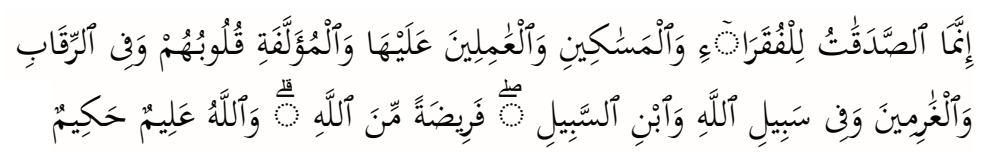

Sesungguhnya zakat-zakat itu, hanyalah untuk orang-orang fakir, orangorang miskin, pengurus-pengurus zakat, para mu'allaf yang dibujuk hatinya, untuk (memerdekakan) budak, orang-orang yang berhutang, untuk jalan Allah dan untuk mereka yuang sedang dalam perjalanan, sebagai suatu ketetapan yang diwajibkan Allah, dan Allah maha mengetahui lagi maha bijaksana. (QS. At Taubah 60)

Adanya ketetapan Asnäf zakat (orang yang berhak menerima zakat) dalam qur'an ini mengindikasikan harta zakat harus ditasyarufkan kepada Asnäf zakat. Para ulama membuat suatu batasan siapa saja yang dianggap sebagai Asnäf zakat dengan cara mendefiniskan satu persatu dari delapan Asnäf tersebut. ${ }^{32}$

Pertama Faqir, Faqir adalah oarng yang tidak mampu untuk melakukan usaha yang dapat mencukupi kebutuahannya sehari-hari, dan tidak mampu bekerja karena tidak kuat atau ada sesuatu kesibukan yang menyebabkan ia tidak dapat bekerja. Kesibukan itu, seperti kesibukan mengajar ilmu tanpa pamri atau menulis buku agama tanpa retrubusi. Dengannya orang disibukan mengajarkan ilmu dan menulis ilmu dan

\footnotetext{
31 Wahbah Zuhaili, al Figh al Islami. 661

${ }^{32}$ Muhammad az Zuhri. Anwar al Masalik.115-116
} 
mereka tidak dapat memenuhi kebutuhannya karena kesibukanya tersebut, maka mereka dapat diberi zakat.

Kedua Miskin, Miskin adalah orang yang mampu melakukan usaha, namun hasil dari usahanya tersebut tidak cukup memenuhi kebutuhan sehari-hari. Semisal setiap hari kebutuhanya Rp.100.000 dan ia hanya bisa mendapat 75 ribu perhari.

Ketiga Amil, Ámil adalah seorang yang diutus oleh pengausa untuk mengelolah zakat. Dalam fikih amil meliputi; as Sä̀ atau orang mencari Asnāf zakat dengan mentaksir harta wajib zakat, al Kätib atau orang yang menulis pungutan zakat dari Muraki, al Härits atau orang yang mengumpulkan zakat dan terakhir adalah al Qäsim atau orang yang membagi harta zakat.

Keempat Mualaf, Mualaf adalah orang yang diharapkan keisilamannya, dalama hal ini mualaf yang masih nonmuslim tidak dapat diberi zakat, akan tetapi mualaf muslim dapat diberi zakat guna ia tetap beragama Islam dan bertambah kuat imamnya.

Kelima Riqāb, Riqāb adalah mereka tergolong budak yang ingin memerdekanan dirinya dengan cara mengansur harga jual dirinya dari pemiliknya. ${ }^{33}$

Keenam Ghärim, Ghärim adalah orang yang berhutang, di mana dana hutang tersebut digunakan untuk kemsalahatan. Dalam hal ini Ghärim yang hutang untuk menafaqahi keluarganya atau hutang untuk mengkondusifkan keadaan masyarakat yang bertikai, mereka dapat menerima zakat.

Ketujuh Fisabilillah, Fissabilillah adalah mereka yang berjuang dijalan Allah dengan cara berperang karena agama Allah.

Kedalapan ibnu as Sabill, ibnu as Sabil adalah orang yang bepergian yang tujuannya tidak maksiat, atau orang yang memberi bantuan kepada orang yang bepergian yang tujuan bepergianya tidak maksiat. Hal ini meskipun orang bepergian tersebut memiliki harta di rumahnya, ia tetap dianggap ibnu as Sabil.

Lalu bagaimana penglolaan zakat pada masa kemasa. Di masa Rasullah, hasil zakat dikumpulkan di Bait al Mäll lalu kemudian ditasyarufkan kepada Asnäf. Meski demikian tidak jarang hasil zakat langsung distasyarufkan kepada Asnäf tanpa disimpan di Bait al Mäll.

\footnotetext{
33 Budak saat ini tidak dapat kita temukan karena Islam menghapus perbudakan, dan budak merupakan warisan jahiliyah yang pelan dihapuskan karena budak merupakan harta benda yang dimilki non muslim sebelum masuk Islam. Islam mengetahui betapa beratnya kehilangan harta benda sehingga ketiaka non muslim jahiliyah masuk Islam syariat tidak menghapuskan perbudakan secara langsung namun syariat mengajarkan pengahpusan dengan cara menetapkan kafarat atau menjajijan kemerdekaan di akhirat bagai mereka yang memerdekan budaknya.
} 
Pada masa ini Rasullah membentuk badan penglolah zakat secara sederhana, dimana secara struktur kita dapat temukan beberapa istilah di dalam kitab fikih klasik, beberapa istilah pengelolah zakat pada masa klasik meliputi; Kätib atau pencatat zakat, Hāsibah atau penghitung kadar zakat, Jubah atau pengutip zakat, Kanzanah atau penjaga harta zakat dan terakhir dikenal pula Qasamah atau pembagi zakat. ${ }^{34}$

Di masa Khulafaurasidin, zakat tetap diberlakukan, meski di zaman Abu Bakar ada orang muslim yang tidak mau menunaikan zakat, di zaman Umar dihapuskan zakat bagi mualaf, di zaman Utsma, Utsman memberlakukan zakat al amwal ad Dabiriyah dan al amwal al Batiniyah yakni barang tampak dan tidak tampak. Barang yang dimaksud tampak (al Dabiriyah) adalah hewan ternak dan hasil bumi, sedang yang dimaksud tidak tampak (al Batiniyah) adalah uang dan juga barang tambang. Sementara itu, pada masa Ali, meski terdapat huru hara pada masa ini, namun perhatian Ali kepada orang miskin dan pengemis sangatlah kentara, hal ini dapat dilihat dari perhatian Ali kepada penegmis nonmuslim yang menurutnya layak diberi sesuatu yang diambilkan dari Bait al Mäll. . $^{35}$

Pada masa at Tabi'in-at Tabi'in pengeloalahan zakat menemui awal perkembangannya. Umar bin Abdul Aziz menetapakan kewajiban zakat pada harta kekayaan yang diperoleh dari profesi seseorang, baik berupa honor pegawai, hasil jasa dan penghasilan. ${ }^{36} \mathrm{Hal}$ ini bukan tidak beralasan, di masa ini kepercayaan masyarakat kepada penguasa sangatlah tinggi, kesejahteraan masyakat tercukupi, sehingga penarikan zakat mudah dilakukan. Bahkan pada masa ini tercatat oleh sejarah sebagai masa di mana sulit ditemukan Asnäf zakat di beberapa wilayah. Sehingga Zakat yang telah dihimpun pada masa ini ditasyarufkan pada wilayah lain.

Pentasyarufan zakat pada masa ulama klasik, yakni pada tahun 702 hijrah juga sudah meperlihatkan penglolahan zakat system modern. Tercatat dalam kitab U'mdat as Sälik wa U'datu an Näsik, bahwa pentasyarufan zakat telah dibagi secara prosentase berdasarkan golongan Asnäf yang ada delapan. Dalam kitab tersebut dijelaskan Faqir dan Miskin mendapat $1 / 8$ dari penghimpunan harta zakat, Amil mendapat $1 / 8$ dari penghimpunan n harta zakat. Amil zakat mendapat bagian $1 / 8$, jika $1 / 8$ harta zakat kurang dari upa kerja Amil perharinya. Jika 1/8 lebih besar

\footnotetext{
34 Mustafa Edwin Nasution, Pengenalan Ekesklusif Ekonomi Islam, Jakarta: Kencana, 2006), Hlm. 214

35 Faisal, Sejarah Pengelolahan Zakat DI Dunia Muslim Dan Indonesia. (Pendekatan Teori Investigasi-Sejarah Charles Peirce dan Defisit Kebenaran Lieven Boeve). Analisis, Volume XI, Nomor 2, Desember 2011. Hlm.248-249

${ }^{36}$ Faisal, Sejarah Pengelolahan Zakat DI Dunia.249
} 
dari upa kerja Ámil perharinya, maka 1/8 dari bagian tersebut harus dikembalikan kelebihanya dan disesuaikan dengan upa kerja perharinya. Asnäf Amil diakui keberadaannya, manakala zakat dihimpun oleh penguasa atau badan yang ditunjuknya. Jika zakat ditasyarufkan atau disalurkan langsug oleh muzaki, maka Asnäf Ämil dianggap tidak ada, karena zakat didistribusikan angsung oleh Muzaki bukan Amil.

Lebih lanjut dalam kitab tersebut menjelaskan, pentasyaufan harta zakat pada Asnäf haruslah sama banyak. Antar golongan Asnäf mendapat $1 / 8$ harta zakat, kecuali Amil yang telah diberi upa dari penguasa bukan dari harta hasil zakat. Amil diberi harta zakat manakala gajinya kurang dari $1 / 8$ harta zakat setelah dibagikan kepada seluruh Amil. Bagaiaman jika beberapa Asnäf zakat tidak ada. Semisal, dalam suatu wilayah pembagian zakat hanya terdapat Asnäf Faqìr dan Miskin, dikarenakan hanya ada dua Asnäf saja, maka skema pentasyarufan zakatnaya dapat dibagi 50\% untuk Asnāf Faqìr dan $50 \%$ untuk Asnäf Miskin. ${ }^{37}$

Skema pentasyarufan zakat kepada Faqir dan Miskin dalam kitab U'mdat as Sälike wa U'datu an Näsike mendapat perhatian lebih luas oleh pengarangnya, hal ini dapat kita lihat paparan beliau; ${ }^{38}$

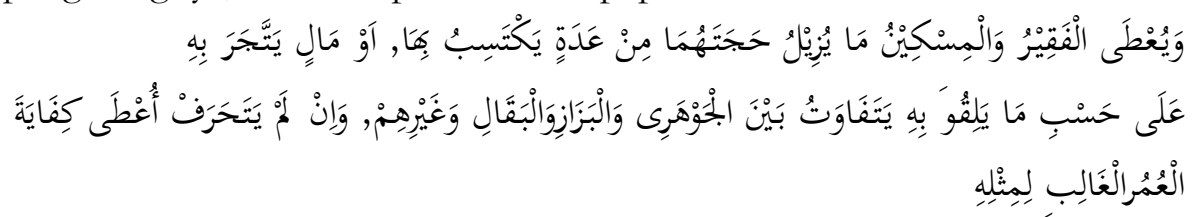

Skema pentasyarufan zakat kepada Faqir dan Miskin dalam kutipan ibarah kitab tersebut setidaknya terdapat tiga skema, Pertama, memberikan harta zakat kepada Faqir dan Miskin sesuai alat yang mereka butuhkan. Kedua, memberikan modal dari harta zakat kepada Faqir dan Miskin sebagai modal berdagang. Ketiga, jika mereka tidak mampu bekerja dan tidak mampu berdagang, maka penguasa memberikan harta zakat kepada Faqir dan Miskin sesuai kebuthan hidupnya selama setahun atau selama masa hidupnya. Sesuai dengan anjuran syariat, bahwa penguasa wajib memelihara dan mensejahterahkan rakyatnya. Syari'at Islam meperbolehkan penguasa mensejahterakan rakyatnya dengan menggunakan harta zakat sumber bantuan kepada mereka.

Pengelolahan zakat semakin berkembang hingga dewasa ini, meski demikian fakar menilai zakat belum mampu menangani beberapa masalah kemiskinan di beberapa negara berpendudk muslim, termasuk negara Indonesia, maka kemudian banyak yang mencoba membuat suatu

\footnotetext{
${ }^{37}$ Muhammad az Zuhri. Anwar al Masalik 114

${ }^{38}$ Muhammad az Zuhri. Anwar al Masalik.115
} 
terobosan agar zakat mampu memecahkan masalah kemiskian tersebut, terlebih zakat dalam Islam memiliki tujuan yang mulia yakni mensejahterakan masyarakat secara umum, selain itu zakat juga bertujuan agar harta tidak dikuasai hanya oleh orang kaya saja.

Beberapa negara Islam saat ini telah berupaya mengoptimalkan harta zakat sebagai pengentas kemiskinan. Skema pentasyarufannya pun sedikit dimodifikasi agar mampu menjawab tatangan isu kemiskinan. Modifikasi yang dimaksud adalah yang tadinya pentasyarufan zakat klasik dimodifikasi menjadi pentasyarufan berbasis produktif. Beberapa produk skema pentasyarufan zakat produktif yang saat ini kita bisa temui meliputi; Pertama. Pentasyarufan zakat produktif dengan pinjaman bergulir, di mana Asnäf zakat sebagai peminjam dana zakat ia bertanggung jawab untuk mengembalikan dana pinjamannya setelah mendapat untung. Kedua, Skema pinjaman bergulir dengan system bagi hasil, di mana Asnäf zakat menerima dana zakat dan mengelolah dana tersebut sebagai modal tambahan, lalu Asnäf berekewajiban mengembalikan modal dan membagi hasil penglolaan kepada Badan Amil Zakat guna ditasyarufkan kembali kepada Asnäflain.

Beberapa skema pentasyarufan di atas merupakan pentasyarufan harta zakat model baru yang tidak diktemukan pada masa Islam klasik. Sekama pentasyarufan zakat pada Islam klasik menggunakan system pemeberian cuma-cuma, Asnäf zakat diberi harta zakat dan tidak dibebani kewajiban mengembalikan harta zakat yang diberikan padanya. Hal ini dapat kita telusuri dibeberapa kitab fikih klaik seperti kitab U'mdat as Sälik wa U'datu an Näsik di atas misalnya. Pentasyarufan harta zakat model skema saat ini bertujuan untuk membangkitkan ekonomi Asnäf yang produktif atau memiliki keingian untuk usaha. Diharapkan dengan pemberian modal tersebut usaha kecilnya dapat bangkit dan berkembang, sehingga akhirnya dapat merubah status sosialnya.

Pentasyarufan zakat dapat dilakukan oleh Muraki (orang wajib zakat), rekan sekutunya, wali dan atau wakilnya kepada Asnäf atau pun kepada amil zakat. Di masa Islam klasik subjek zakat hanya manusia. Pada saat ini subjek zakat bukan hanya manusia tapi juga badan hukum. ${ }^{39}$ Badan hukum yang termasuk subjek zakat adalah sebuah perusahaan yang dimiliki oleh orang muslim atau pun perusahaan yang mayoritas pemegang sahamnya adalah orang muslim. ${ }^{40}$

${ }^{39}$ Lihat Bab I pasal 1 poin 2 dan 5 Undang- Undang Republik Indonesia Nomor 23 Tahun 2011 Tentang Pengelolaan Zakat

40 Lihat surat keputusan dewan pertimbangan amil zakat nasional No:001/DPBAZNAS/XII/2010 Tentang Pedoman dan Pentasyarufan zakat, Infak dan Shadaqah Badan Amil Zakat Nasional 
Penetasyarufan zakat oleh Muzaki dianggap tidak dapat merubah keadaan ekonomi Asnäf zakat, hal ini dikarekan pentasyarufan secara langsung kepada Asnäf bersifat konsumtif, sebab itu dibutuhkan lembaga penglola zakat. Kehadiran penglola zakat diharapkan mempu mengoptimalkan penghimpunan dan pentasyarufan harta zakat sebagai jawaban masalah-maslah kemiskinan, kekurangan gizi dan tunawisma di negara berpenduk mayoritas muslim. Badan pengelola zakat diharapkan bukan hanya dapat menghimpun dan mentasyarufkan harta zakat tapi juga dapat pentasyarufan zakat dengan beberapa model skema pentasyarufan. Skema pentasyarufan yang dimaksud adalah, pemberian modal bagi Asnäf yang memiliki usaha, memberi pembiayan pengembangan kemapuan usaha bagi mereka yang kurang trampil, menggunakan harta zakat sebagai modal pengembangan UMKM yang dapat memperdayakan Asnäf sebagai tenaga pekerjanya, memeberikan sebuah alat yang dibutuhkan untuk bekerja atau usaha, dan memberi hewan ternak kepada Asnäf yang membutuhkan dan trampil memelihranya.

\section{Analisis Skema Pentasyarufan Zakat Dalam Fatwa MUI No 23 Tahun 2020 Tentang Pemanfatan Harta Zakat Untuk Penanggulangan Wabah Covid-19 Dan Dampaknya}

Fatwa MUI No 23 Tahun 2020 Tentang Pemanfatan Harta Zakat, Infak, Dan Shadaqah Untuk Penanggulangan wabah Covid-19 dan Dampaknya ditetapkan pada 16 April 2020 M atau stelah beberapa bulan Indonesia dinyatakan darurat pendemi covid 19. Fatwa ini menetepkan beberapa ketentuan, ketentuan-ketentuan tersebut meliputi; Ketentuan Umum, Ketentuan Hukum, Ketentuan Rekomendasi dan terakhir Ketentuan Penutup. Di antara beberapa ketentuan tersebut, fokus analisa penulis pada fatwa tersebut adalah pada ketentuan umum dan ketentuan hukum, hal ini karena kedua ketentuan tersebut merupakan produk fatwa hukum yang dihasilkan oleh perumus fatwa. Dari kedua ketentuan tersebut pulalah kita dapat ketahui apakah hasil fatawa tersebut sesuai dengan syariat Islam atau tidak.

Pada ketentuan umum fatwa ini menegaskan beberapa istilah, istilah meliputi; istilah Pemanfaatan zakat, Hawalan al-haul, Penanggulangan wabah Covid 19 dan dampaknya, dan terakhir dijelaskan pula istilah Aset kelolahan. Dalam ketentuan umum ditentukan bahwa pemanfaatan zakat, infaq dan shadaqah ditasyarufkan kepada penerima dan pengguaan tersebut secara tepat. ${ }^{41}$ Adapun skema pentasyarufan

\footnotetext{
${ }^{41}$ Lihat ketentuan Umum poin 1 Fatwa MUI No 23 Tahun 2020 Tentang Pemanfatan Harta Zakat Untuk Penanggulangan Wabah Covid-19 Dan Dampaknya
} 
zakat untuk penangan covid 19 pada ketentuan umum ini dijelakan oleh ketentuan hukum.

Pada ketentuan hukum, fatwa ini membahas tentang 1). Kebolehan hukum zakat untuk penanggulangan wabah Covid 19 dan dampaknya dengan syarat mengikuti batas yang ditetapkan dalam fatwa tersebut. 2). Kebolehan hukum men-ta'zil zakat (mendahulukan zakat dari haul-nya) dengan syarat harta yang dikeluarkan zakatnya harus sudah satu nisab. 3). kebolehan hukum men-tajizil zakat fitrah dengan syarat penuaian zakat fitra dilakuan setelah masuk bulan Ramdhan dan. 4). Ketentuan penanggulangan Covid 19 yang tidak dapat menggunakan zakat, boleh menggunakan harta infaq dan shadaqah.

Ketentuan hukum poin 1 ayat a dan b mejelaskan, penditribusian zakat dapat dilakukan dengan skema pentasyarufan secara langsung, dan dapat pula dilakukan dengan skema pentasyarufan secara tidak langsung atau pentasyarufan dengan cara dikelolah sebagai pembiayaan kepentingan kemaslahatan umum.

Pentasyarufan harta zakat kepada Asnäf dengan skema langsung harus mengikuti ketentuan sebagai berikut: 1). Penerima termasuk salah satu golongan (Asnäf) zakat, yaitu muslim yang fakir, miskin, amil, muallaf, yang terlilit hutang, riqab, ibnu sabil, dan/atau fi sabilillah. ${ }^{42}$ Dilihat dari ketentuan ini jelas pentasyarufan harta zakat dalam fatwa tersebut tidak keluar dari ketentuan syari'at, di mana syari'at menetapkan bahwa zakat harus diberikan kepada Asnäf zakat yang ada delapan golongan sebagai mana disebutkan dalam Qur'an suat at Taubah ayat 60. Para fukoha juga telah sepakat tentang hal tersebut, bahwa pentasyarufan zakat harus kepada asnaf zakat.

Dalam ketentuan hukum fatwa tersebut juga telah menjelaskan dua skema pentasyarufan zakat untuk penangan covid 19. Yaitu penangan zakat langsung dan tidak langsung.

Skema pentasyarufan zakat secara langsung sesuai dengan ketentuan hukum pada fatwa ini bahwa, poin 1 ayat a (2) menjelaskan bahwa harta zakat yang didistribusikan boleh dalam bentuk uang tunai, makanan pokok, keperluan pengobatan, modal kerja, dan yang sesuai dengan kebutuhan Asnäf. ${ }^{43}$ Selaras dengan pendapat para ulama salaf bahwa pentasyarufan zakat mäll tidak dibatasi dengan objek tertentu pada saat pentasyarufannya. Dengannya zakat mäll dapat ditasyarufkan berupa

42 Lihat Ketentuan Hukun Poin 1 (a) Fatwa MUI No 23 Tahun 2020 Tentang Pemanfatan Harta Zakat Untuk Penanggulangan Wabah Covid-19 Dan Dampaknya 43 Lihat Ketentuan Hukun Poin 1 a (2) Fatwa MUI No 23 Tahun 2020 Tentang Pemanfatan Harta Zakat Untuk Penanggulangan Wabah Covid-19 Dan Dampaknya 
uang tunai, makanan pokok dan modal, sebagaimana hal ini telah dijelaskan oleh Syihabudin sebelumnya di atas.

Selain bentuk di atas, ketentaun hukum poin 1 ayat a (3) fatwa ini juga menyinggung pemanfaatan harta zakat boleh bersifat produktif, antara lain untuk stimulasi kegiatan sosial ekonomi fakir miskin yang terdampak wabah. Ketentuan hukum ini memunculkan khilaf dikalangan ulama modern.

Ada yang memperbolehkan pengelolaan zakat dengan skema produktif, namun ada pula yang tidak memperbolehkan. Mereka yang memperbolehkan pentasyarufan zakat dengan skema zakat produktif berlasan, bahwa tujuan pembagian zakat secara subtansi adalah kesejahteraan Asnäf dan perubahan status sosial Asnäf yang awalnya kekurangan menjadi berkecukupan bahkan lebih. Jika zakat ditasyarufkan secara konsumtif, maka harta zakat akan cepat habis dan tidak mengubah perekonomian dan status social Asnäf. Lebih lanjut mereka yang memperbolehkan pengeloahan zakat dengan skema zakat produktif berpendapat, bahwa pentasyarufan zakat produktif menggunakan akad qordul hasan, dimana muzaki sebagai penghutang dan ia wajib mengembalikan pada waktu yang ditentukan. Upaya ini dianggap lebih tepat dan paling mudah untuk memutar kembali hasil zakat kepada Asnäf lain yang membutuhkan modal.

Sedang mereka yang tidak memperbolehkan zakat ditasyarufkan dengan skema zakat produktif, hal ini karena mereka berpegang bahwa fekih klasik yang tidak menjelaskan skema pentasyarufan harta zakat kepada Asnäf dengan status hutang. Fikih klasik menjelsakan bahwa pentasyarufan harta zakat pada Asnāf bersifat free atau sukarela tanpa ada kewajiban membayar hutang.

Selanjutnya skema pentasyarufan zakat tidak langsung atau hasil perhimpuan harta zakat digunakan sebagai pemenuhan kepentingan kemaslahatan umum. Adapun sayarat zakat dapat ditasyarufkan untuk kepentingan kemaslahatan umum dalam fatwa tersebut meliputi; 1). Penerima manfaat termasuk golongan (Asnäf) fi sabilillah. 2). Pemanfaatan zakat dalam bentuk aset kelolaan atau layanan bagi kemaslahatan umum, khususnya kemaslahatan Asnäf, seperti untuk penyediaan alat pelindung diri, disinfektan, dan pengobatan serta kebutuhan relawan yang bertugas melakukan aktifitas kemanusiaan dalam penanggulangan wabah.

Selaras dengan ketentuan fikih klasik, bahwa harta zakat mäll dalam fikih klasik pada dasaernya berupa hal yang dibutuhkan oleh Asnāf.

44 Ketentuan Hukum Poin 1 ayat a (1) Fatwa MUI No 23 Tahun 2020 Tentang Pemanfatan Harta Zakat Untuk Penanggulangan Wabah Covid-19 Dan Dampaknya 
Saat pandemi covid, kebutuhan alat pelindung diri atau obat-obatan adalah yang paling dibutuhkan oleh Asnāf atau perawat yang merawatnya saat di ruang isolasi pasien covid 19, tentu asas prioritas pengeloaan zakat harus mengedepankan kebutuhan ini sebagai dasar pentasyarufan zakat tidak langsung

Skema pentasyarufan zakat tidak langsung juga kita dapat temukan pada ketentuan umum poin 3 fatawa ini. Poin tersebut mengatakan, penanggulangan wabah COVID-19 dan dampaknya adalah segala ikhtiar yang ditujukan untuk mencegah penyebaran COVID-19, merawat dan menangani korban COVID-19, memperkecil angka kematian, membatasi penularan dan penyebaran penyakit agar wabah tidak meluas ke daerah lain, serta membantu kesulitan umat Islam yang terdampak COVID-19. Pentasyarufan zakat dengan skema ini seolaholah tidak menggunakan qordul hasan, malainkan penyaluran langsung kepada Asnäf yang terdampak covid 19. Sehingga dapat disimpulkan, pentasyraufan zakat pada saat pandemi covid 19 tidak masuk dalam khilafiyah.

Selanjutnya ketentuan hukum fatwa ini juga menegaskan bahwa, jika ada kebutuhan penanggulangan wabah COVID-19 dan dampaknya yang tidak dapat dipenuhi melalui harta zakat, dapat diperoleh melalui infaq, shadaqah, dan sumbangan halal lainnya. Ini mengaskan bahwa perumus fatwa juga menyadari bahwa dalam penangan covid 19 tidak melulu secara mutlak dapat menggunakan dana zakat. Perumus fatwa seolah menyadari bahwa tidak semua penangan covid dapat dibiayai oleh zakat.

Selain skema pentasyarufan zakat untuk penanggulangan covid, fatwa ini juga menjelaskan mekanisme pentasyarufan zakat. Mengutip ketentuan hukum poin 2-3, bahwa Zakat mäll boleh ditunaikan dan disalurkan lebih cepat (tajil al zakah) tanpa harus menunggu satu tahun penuh (Hawalan alhaul), apabila telah mencapai nishab. Sedang Zakat fitrah boleh ditunaikan dan disalurkan sejak awal Ramadhan tanpa harus menunggu malam idul fitri. Berkaitan tentang me-nta'jil zakat. Tentunya pengimpunan zakat dengan men-ta'jil pentasyarufanya harus dilakukan dengan jalan hati-hati, sebab beberapa pendapat ulama tidak memutklakan kebolehan men-ta'jil zakat. Kebolehen men-ta'jil zakat harus mengikuti beberapa syarat yang telah dijelaskan sebelumnya. Kehati-hatian pada saat men-ta'jil berkaitan, apakah Asnäf yang diberi termasuk ketegori asnaf atau tidak, dan Muqaki tetap menajdi Muzaki sampai dating haul atau tidak, berkaitan tentang hal ini telah dijelaskan sebelumnya di atas.

Untuk mengotimalkan perehimpuan dan pentasyarufan zakat, fatwa ini membuat ketentauan rekomendasi. Ketentuan rekomendasi 
poin 2-4 menyebutkan bahwa. 1) Umat Islam diharapkan menyalurkan zakatnya melalui badan/lembaga amil zakat yang terpercaya agar manfaatnya nyata. 2) Badan/Lembaga Amil Zakat agar menjadikan fatwa ini sebagai pedoman dalam pengelolaan zakat dengan memprioritaskan Tasharruf khususnya untuk kemaslahatan Asnäf yang terdampak Covid 19. 3) Umat Islam yang memenuhi syarat wajib zakat dianjurkan untuk segera menunaikan kewajiban zakatnya agar para Asnäf yang terdampak Covid 19 dapat memperoleh haknya. Hal ini adalah hal yang harus diuapayakan, bahkan jika Muzaki membandal untuk metasyarufkan zakatnya penguasa dapat mengeluarkan aturan agar Muqaki dapat menunaikan zakat. Berpedoman pada diperkenankannya pengusa memungut zakat dengan paksa bagi Muqaki yang enggan, bukan tidak mungkin presiden mengeluarkan perturan pemungutan zakat pada masa pandemi covid 19.

\section{Kesimpulan}

Dari paparan di atas peneliti dapat menyimpulkan beberapa kesimpulan berkaitan studi fikih dan Fatwa MUI No 23 Tahun 2020 Tentang Pemanfatan Harta Zakat Untuk Penanggulangan Wabah Covid19 Dan Dampaknya sebagiama berikut:

Skema pentasyarufan zakat pada Fatwa MUI No 23 Tahun 2020 Tentang Pemanfatan Harta Zakat Untuk Penanggulangan Wabah Covid19 Dan Dampaknya terdiri dari dua skema; Pertama skema pentasyarufan zakat secara langsung oleh Muzaki atau BAZNAZ kepada Asnäf yang terdampak covid 19. Kedua pentasyarufan zakat dengan skema tidak langsung, di mana Muraki atau BAZNAS menggunakan hasil zakat untuk membeli kebutuhan APD bagi perawat dan relawan atau alat medis penunjang pencegahan covid 19.

Selanjutnya Mekasime pentasyarufa zakat oleh Muraki dapat dilakukan dengan cara men-ta'jil sebelum waktu haul tiba dengan syarat harta telah mencapai satu nisab untuk zakat Mall dan telah masuk ramadan untuk zakat fitra, hal ini karena dampak pandemi covid 19 bagi perekonomian Asnäf sangatlah terasa.

Dan juga 'Ámil zakat dalam hal ini BAZNAS harus berhati-hati dalam mentasyarufkan hasil zakat, mengingat masyarakat yang terdampak covid bukan hanya Asnäf zakat saja melainkan seluruh masyarakat Indonesia, baik kaya atau miskin, baik muslim atau non muslim. 


\section{DAFTAR PUSTAKA}

Bayjori. Ibrahim (al), Hasyiah as Syaikh Ibrahim al Bayjori ala Syarah Ibnu Qasim al Ghazri ala Matn Abi Suja'. (Beirut, Dar al Kotob Al Ilmiyah, 2015). Juz.I

Faisal, Sejarah Pengelolahan Zakat DI Dunia Muslim Dan Indonesia. (Pendekatan Teori Investigasi-Sejarah Charles Peirce dan Defisit Kebenaran Lieven Boeve). Analisis, Volume XI, Nomor 2, Desember 2011.

Fatwa MUI No 23 Tahun 2020 Tentang Pemanfatan Harta Zakat Untuk Penanggulangan Wabah Covid-19 Dan Dampaknya

Fayruz, Ibrahim (al), Al Mubaddab fi Fiqh al-Imam Syafii, (Beirut, Dar al Kotob Al -Ilmiyah, 2011). Juz.I

https://money.kompas.com/read/2020/07/15/150436926/bpsdampak-covid-19-penduduk-miskin-naik-jadi-2642-jutaorang?page $=$ all.

https://nasional.kompas.com/read/2020/03/26/07412441/9kebijakan-ekonomi-jokowi-di-tengah-pandemi-covid-19penangguhan-cicilan?page $=$ all

https://www.bbc.com/indonesia/dunia-53168814

https://www.cnnindonesia.com/nasional/20200904151608-20542861/update-corona-4-september-187537-positif-134181sembuh

https://www.kompas.com/sains/read/2020/05/11/130600623/diumu mkan-awal-maret-ahli--virus-corona-masuk-indonesia-darijanuari\#: :text=KOMPAS.com $\% 20 \% 2 \mathrm{D} \% 20 \mathrm{Pada} \% 202 \% 20 \mathrm{Ma}$ ret,ke\%20Indonesia $\% 20$ sejak $\% 20$ awal $\% 20$ Januari.

Keputusan dewan pertimbangan amil zakat nasional No:001/DPBAZNAS/XII/2010 Tentang Pedoman dan Pentasyarufan zakat, Infak dan Shadaqah Badan Amil Zakat Nasional

Keputusan Ketua Badan Amil Zakat Nasioanl No 142 Tahun, 2017 tetang Nilai Nisab Zakat Pendapatan Tahun 2017 di seluruh Wilayah Indonesia

Malibari, Zaynudin al, Fatbul Mu'in, (Beirut, Dar al Kotob al Ilmiyah, 2015).

Nasution, Mustafa Edwin. Pengenalan Eksklusif Ekonomi Islam, Jakarta: Kencana, 2006)

Sabiq, Sayid.Fiqhu as Sunnah, (Beirut, Maktabah al Ashriyah 2011). Juz I.

Syafii, Muhammad (as), al Umm, (Beirut, Dar al Kotob Al -Ilmiyah, 2014), Juz II. 
Syamsudin. Muhammad. Nibayatu al Mubtaj ila Syabri al Mubadzab, (Mesir, al Maktabah al Taufikiya, 2012). Juz III.

Undang- Undang Republik Indonesia Nomor 23 Tahun 2011 Tentang Pengelolaan Zakat

Zuhaili. Wahbah, al Fiqh al Islami wa Adilatubu, (Berut, Dar al Fikr, 2014). Juz. II.

Zuhri. Muhammad az). Anwar al Masalik Syarah Umdatu as Salik wa Umdatu an Nasik. (Surabaya, al Hidayah, TT). 